\title{
Seasonal variation in sediment urea turnover in a shallow estuary
}

\author{
Mette S. Therkildsen, Bente Aa. Lomstein
}

Department of Microbial Ecology, Institute of Biological Sciences, University of Aarhus, DK-8000 Aarhus, Denmark

\begin{abstract}
A seasonal study of sediment urea turnover rates was carried out in a shallow Danish estuary. Turnover rates decreased with sediment depth $(0$ to $16 \mathrm{~cm})$ and were within the range 1.2 to $424.8 \mathrm{nmol} \mathrm{N} \mathrm{cm} \mathrm{nd}^{-3} \mathrm{~d}^{-1}$. Integrated (0 to $16 \mathrm{~cm}$ depth) turnover rates varied between 1.5 and $16.9 \mathrm{mmol} \mathrm{N}$ $\mathrm{m}^{-2} \mathrm{~d}^{-1}$ with a maximum in July and a minimum in January. Urea turnover followed first-order rate kinetics, as the urea turnover rate constant, $k_{\text {urea }}$, was independent of the urea concentration, and the urea turnover rates were positively related to the latter. The urea turnover rate and rate constant were positively related to temperature. Urea production was stimulated by availability of high quality organic material (low $\mathrm{C} / \mathrm{N}$ ) and temperature. Urea production rates and urea concentrations in the sediment reached a maximum in July, when $\mathrm{C}$-mineralization, temperature, and the quality of organic material were maximal, and there was a high benthic macrofaunal biomass. Secondary maxima in urea concentrations matched major phytoplankton sedimentation events in spring and autumn. Urea- $\mathrm{N}$ accounted for 7 to $55 \%$ of the total $\mathrm{N}$ pool (urea $+\mathrm{NH}_{4}{ }^{+}+\mathrm{NO}_{3}{ }^{-}+\mathrm{NO}_{2}{ }^{-}$) in the sediment surface $(0$ to $1 \mathrm{~cm})$. The $\mathrm{NH}_{4}{ }^{+}$pool was positively related to the urea turnover rate $\left(\sum 0\right.$ to $\left.16 \mathrm{~cm}\right)$. Urea turnover accounted for a major part of the $\mathrm{NH}_{4}{ }^{+}$production in the sediment.
\end{abstract}

KEY WORDS: Urea turnover · Seasonal variation · Marine sediment

\section{INTRODUCTION}

The organic nitrogen compound, urea, has long been recognized as an important nitrogen source for primary producers in marine environments (Remsen 1971, Eppley et al. 1973, McCarthy et al. 1977. Harrison et al. 1985, Sörensson \& Sahlsten 1987, Price \& Harrison 1988, Antia et al. 1991, Cochlan \& Harrison 1991). Urea is excreted as an endproduct of nitrogen metabolism by a variety of marine invertebrates (Wright 1975, Regnault 1987, Boucher \& BoucherRodoni 1988, Stickle 1988, Lomstein et al. 1989) including zooplankton (Eppley et al. 1973). Bacterial decomposition of organic material can also lead to urea production (Satoh 1980, Pedersen et al. 1993a, b), and urea is a well-known product of general purine catabolism (Vogels \& Van der Drift 1976, Mobley \& Hausinger 1989). Human pollution is a potential urea source in coastal marine environments (Paasche \& Kristiansen 1982, Gunkel \& Jessen 1986, Gunkel et al. 1990). Urea is turned over rapidly to yield $\mathrm{NH}_{3}$ and
$\mathrm{CO}_{2}$ and is therefore of potential importance in the production of $\mathrm{NH}_{4}{ }^{+}$. Turnover times of the urea pool in the euphotic zone in the sea vary between 1 and $98 \mathrm{~d}$ (Remsen et al. 1974, Herbland 1976, Kokkinakis \& Wheeler 1988).

Urea plays a significant role in the production of $\mathrm{NH}_{4}{ }^{+}$in marine sediments, and turnover times of urea are on a scale of hours instead of days (Lomstein et al. 1989, Lund \& Blackburn 1989, Lomstein \& Blackburn 1992, Pedersen et al. 1993a). The turnover rate of urea is stimulated by the availability of high quality organic material and the presence of benthic macrofauna, due to concomitant enhanced urea production (Lomstein et al. 1989, Lomstein \& Blackburn 1992).

Urea turnover is likely to be catalyzed by the enzyme urease. Urease is synthesized by many eucaryotes including some invertebrates and numerous microorganisms. Urease activity has been found in a variety of different bacterial divisions comprising bacteria with aerobic and anaerobic metabolism (Mobley \& Hausinger 1989). 
The purpose of the present study was to obtain information on the main factors controlling urea turnover in marine sediments from a shallow estuary. This was illustrated by a study of seasonal variations in urea turnover rates and the major potential controlling factors such as sediment organic carbon and nitrogen content, the quality of organic material ( $\mathrm{C} / \mathrm{N}$ ratio), benthic macrofaunal biomass, chlorophyll a + pheopigment content, and total $\mathrm{C}$-mineralization. Seasonal variation in these major potential controlling factors are discussed in Therkildsen \& Lomstein (1993).

\section{MATERIALS AND METHODS}

Study area. Norsminde Fjord is located on the east coast of Jutland, Denmark. The mean water depth is $0.6 \mathrm{~m}$ (max. $2.0 \mathrm{~m}$ ), and it covers an area of $1.86 \mathrm{~km}^{2}$. Norsminde Fjord is connected to Aarhus Bay and the Kattegat through a narrow sluice-regulated entrance. The main input of freshwater comes from Odder $\AA$, a small river, which is loaded with nutrients from surrounding farmland (Aarhus Amtskommune 1982).

There was no temperature or salinity stratification of the water column at the sampling station. The temperature varied between 0.5 and $20.0^{\circ} \mathrm{C}$ during the year with a maximum in July and a minimum in February, and the salinity varied between 15.0 to $26.8 \%$. The bottom water $\mathrm{O}_{2}$ concentration varied between 270 and $510 \mu \mathrm{M}$ and reached a minimum during summer. The sediment was composed of fine- and mediumsized sand and had a low content of organic material. Data on the sediment density and porewater content are given in Therkildsen \& Lomstein (1993). The sediment was highly bioturbated and the benthic macrofauna was dominated by the polychaete Nereis spp. and the crustacean Corophium volutator (Therkildsen \& Lomstein 1993).

Sampling. Sampling was carried out in the northern part of the estuary near the sea entrance at monthly intervals from September 1990 to November 1991. Sediment cores ( $2.6 \mathrm{~cm}$ i.d.) were taken using Plexiglass tubes and were brought back to the laboratory immediately for further processing. All experiments were performed at the field temperature and in the dark.

Urea turnover and urea sediment pool. Urea turnover rates were measured by the Lund \& Blackburn (1989) ${ }^{14} \mathrm{C}$-urea short-term incubation technique, with the minor modifications described in Lomstein \& Blackburn (1992). Depending on the season, the incubation time varied between 0.5 and $2.0 \mathrm{~h}$. Cores, used for measurements of urea turnover rates and urea pool sizes, were fractioned into $1 \mathrm{~cm}$ segments in the upper 0 to $2 \mathrm{~cm}$ and into $2 \mathrm{~cm}$ segments in the 2 to $16 \mathrm{~cm}$ stratum. Urea turnover rates were calculated using Lund \&
Blackburn's (1989) Model I or Model II, dependent on whether or not the urea concentration in specific sediment strata remained constant during incubation. Urea concentrations were determined by the diacetylmonoxime method described in Price \& Harrison (1987).

Accessibility of the urea pool. A urease solution (McCarthy 1970) was added to $20 \mathrm{ml}$ porewater samples and incubated at room temperature in the dark. The concentration change of urea in the porewaterurease mixture was followed with time. At regular time intervals $0.6 \mathrm{ml}$ samples were taken from the mixture. Reagents from the diacetylmonoxime urea method (Price \& Harrison 1987) were added to the samples immediately to terminate activity,

\section{RESULTS}

\section{Urea sediment pool}

Sediment urea concentrations showed a pronounced seasonal variation (Fig. 1a). Urea concentrations were $>2 \mathrm{nmol} \mathrm{N} \mathrm{cm}^{-3}$ in the upper $4 \mathrm{~cm}$ of the sediment in the periods from December to the middle of February and from May to the middle of June, whereas the $2 \mathrm{nmol} \mathrm{N} \mathrm{cm} \mathrm{cm}^{-3}$ isoline penetrated deeper in the remaining part of the year. Urea concentrations at the
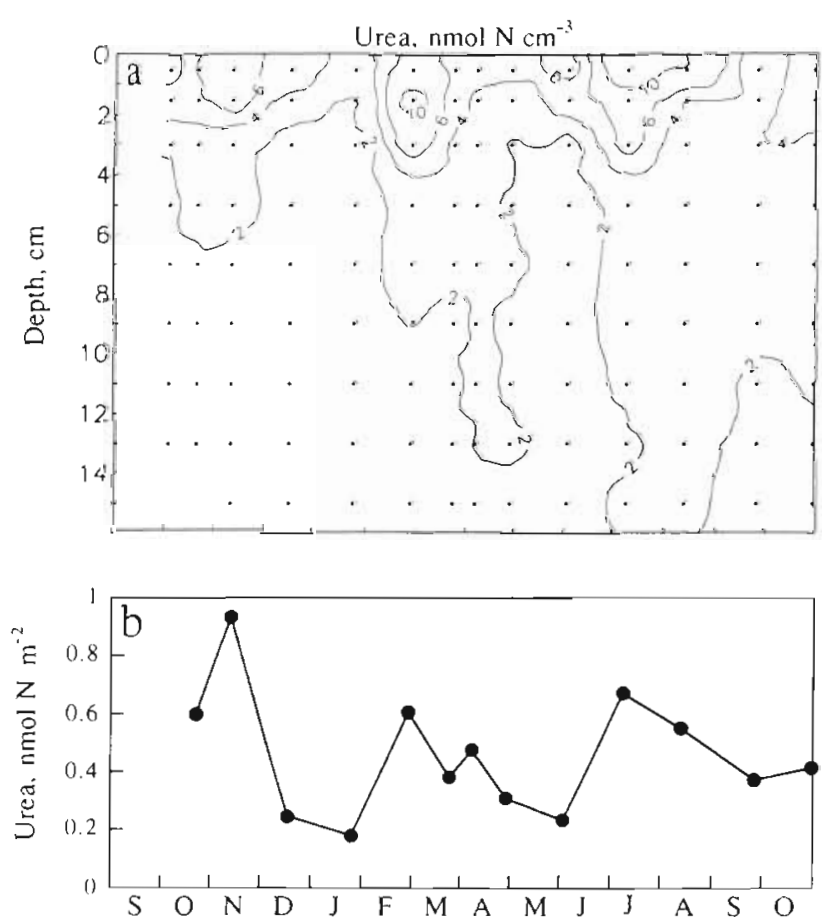

Fig. 1. Seasonal variation in (a) sediment urea concentrations; (b) integrated (0 to $16 \mathrm{~cm})$ urea pools 
sediment surface ( 0 to $1 \mathrm{~cm}$ ) reached a maximum of $15.0 \mathrm{nmol} \mathrm{N} \mathrm{cm}{ }^{-3}$ in July, and a minimum of $2.9 \mathrm{nmol}$ $\mathrm{N} \mathrm{cm}^{-3}$ in late September 1991. Integrated (0 to $16 \mathrm{~cm}$ ) urea concentrations were $\geq 0.5 \mathrm{mmol} \mathrm{N} \mathrm{m}{ }^{-2}$ in late February-April, July-August and October-November (Fig. 1b), whereas the urea concentrations varied between 0.2 and $0.4 \mathrm{mmol} \mathrm{N} \mathrm{m}^{-2}$ during the remaining period.

\section{Urea turnover}

The urea turnover rate constant, $k_{\text {urea, }}$ was generally highest in the upper $2 \mathrm{~cm}$ of the sediment and decreased gradually at depth $>2 \mathrm{~cm}$ (Fig. 2a). The penetration depth of the $0.6 \mathrm{~h}^{-1}$ isoline gradually increased from $2-5 \mathrm{~cm}$ in March-April to a maximum of 11-12 cm in May to July. From August-September to November the penetration depth of the $0.6 \mathrm{~h}^{-1}$ isoline gradually decreased to $1 \mathrm{~cm}$. $k_{\text {urea }}$ was lower than $0.6 \mathrm{~h}^{-1}$ in all sediment strata in December and January. A $k_{\text {urea }}>1.2 \mathrm{~h}^{-1}$, which is equivalent to a turnover time of the urea pool of $<50 \mathrm{~min}$, was found within the
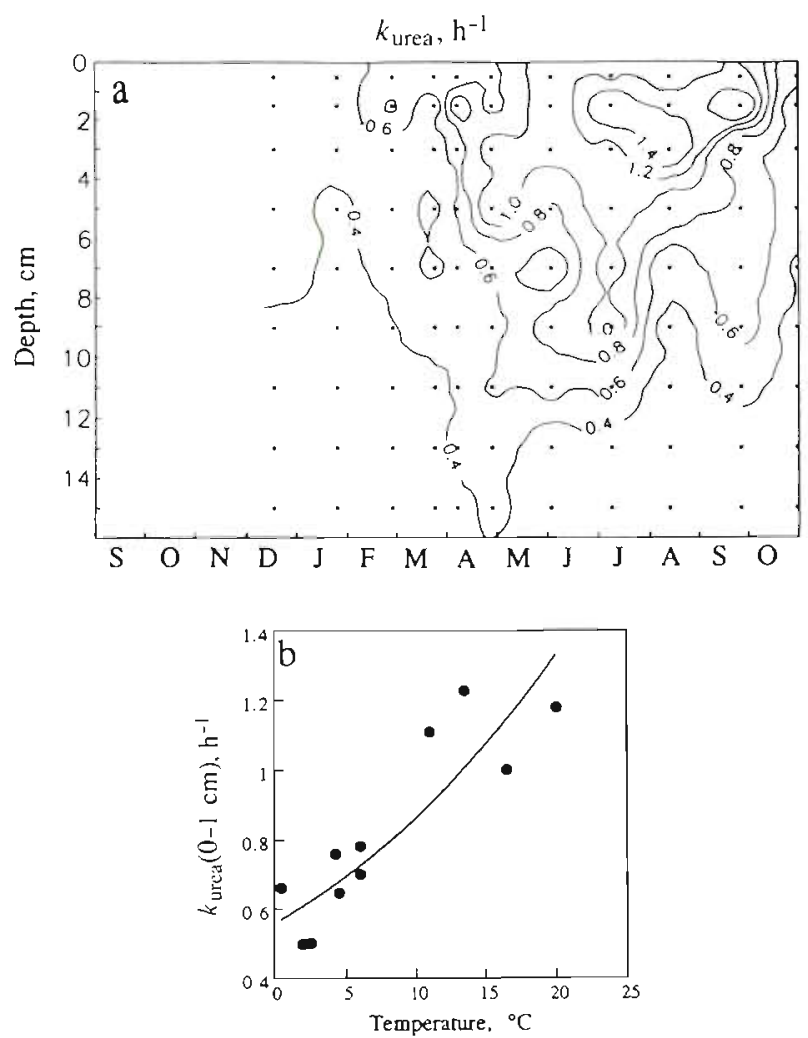

Fig. 2. (a) Seasonal variation in sediment urea turnover rate constants, $k_{\text {urea }}$ (b) Relationship between $k_{\text {urea }}(0$ to $1 \mathrm{~cm})$ and bottom water temperature $[y=0.56 \exp (0.044 x)]$. There are no data available for $k_{\text {urea }}$ in September-November 1990, as all the injected ${ }^{19} \mathrm{C}$-urea was turned over during the incubations
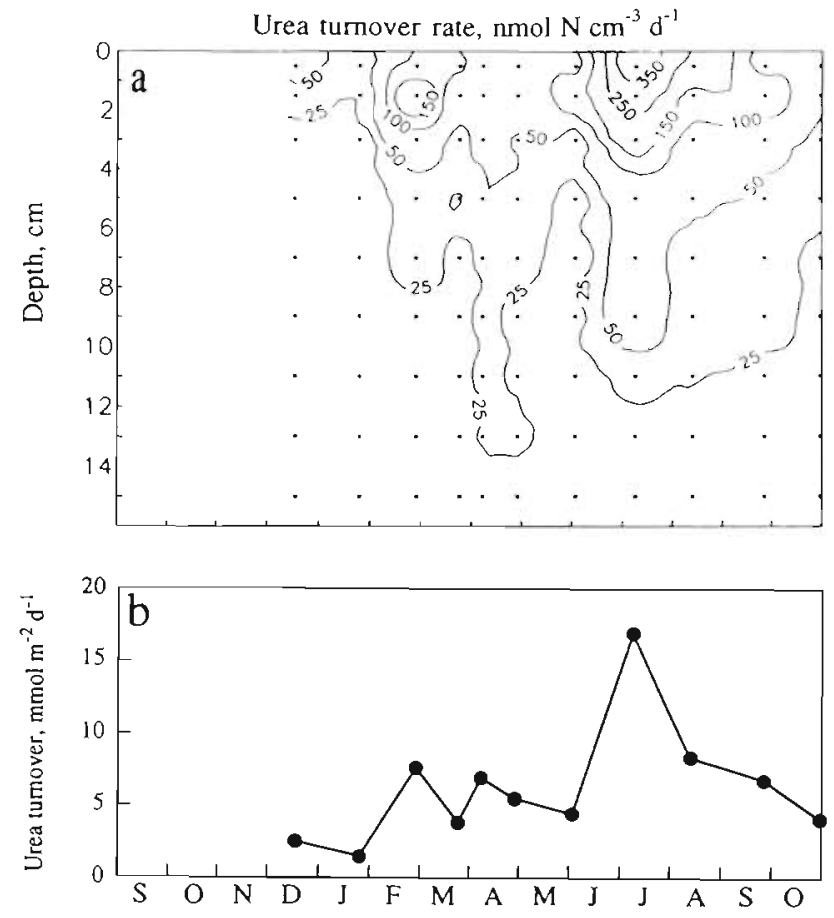

Fig. 3. Seasonal variation in (a) sediment urea turnover rates; (b) integrated $(0$ to $16 \mathrm{~cm}$ ) urea turnover rates

upper $4 \mathrm{~cm}$ of the sediment in the period from July to October.

The turnover rate constants found in the different sediment strata were significantly and positively related to bottom water temperature ( $r=0.86$; Fig. $2 b$ ). There was no relationship between $k_{\text {urea }}$ and the urea pool (data not shown).

Urea turnover rates varied between 1.2 and 424.8 nmol $\mathrm{N} \mathrm{cm}^{-3} \mathrm{~d}^{-1}$. In December-January and October urea turnover rates were $<25 \mathrm{nmol} \mathrm{N} \mathrm{cm}^{-3} \mathrm{~d}^{-1}$ below $6 \mathrm{~cm}$, while the penetration depth of turnover rates $>25 \mathrm{nmol} \mathrm{N} \mathrm{cm} \mathrm{cm}^{-3} \mathrm{~d}^{-1}$ increased to a maximum of $14 \mathrm{~cm}$ in April (Fig. 3a). Urea turnover rates reached a maximum in July (Fig. 3a, b).

There was a positive relationship between urea turnover rates ( $\sum 0$ to $16 \mathrm{~cm}$ ) and urea pools ( $\sum 0$ to $16 \mathrm{~cm})$ in the sediment $(\mathrm{r}=0.84$; Fig. $4 \mathrm{a})$. A similar relationship was found between these 2 parameters in the surface 0 to $1 \mathrm{~cm}$ layer ( $\mathrm{r}=0.96$; data not shown) and in the other strata. Urea turnover rates $\left(\sum 0\right.$ to $\left.16 \mathrm{~cm}\right)$ showed a positive relationship with temperature ( $\mathrm{r}=$ 0.82 ; Fig. 4 b). The temperature coefficient $Q_{10}$, which is the factor of rate increase per $10^{\circ} \mathrm{C}$ temperature increase, was 2.3 .

Urea production rates were calculated by adding urea turnover rates, urea efflux rates (Therkildsen \& Lomstein unpubl.), and changes in the urea pool (Fig. 5). 

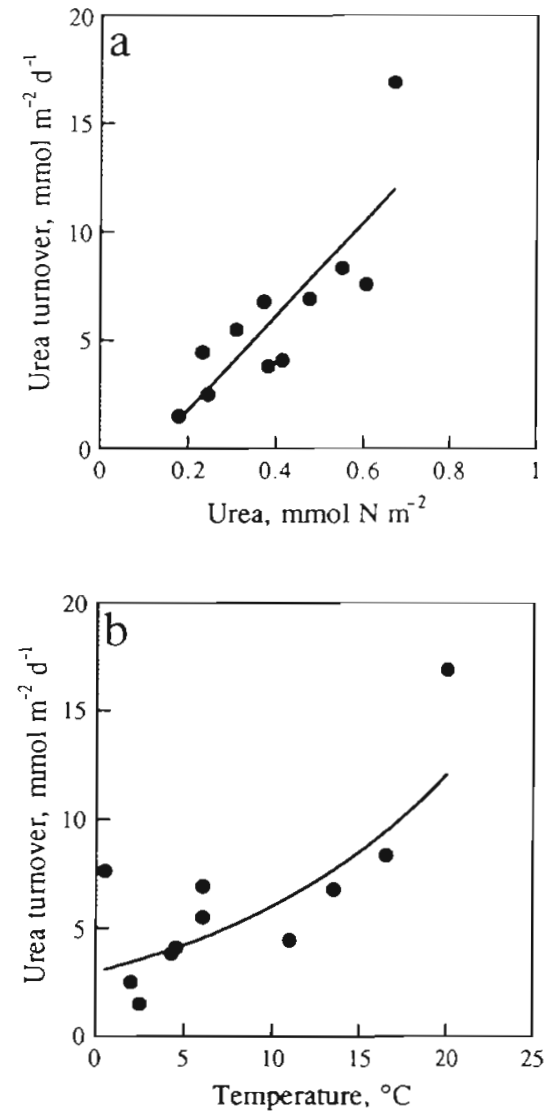

Fig. 4. Relationships between integrated $(0$ to $16 \mathrm{~cm})$ urea turnover rates and (a) the integrated (0 to $16 \mathrm{~cm}$ ) urea pools; (b) the temperature $[y=2.98 \exp (0.07 x)]$

\section{Accessibility of the urea pool}

The initial porewater concentration of urea was $42 \mu \mathrm{mol} \mathrm{N} \mathrm{l}^{-1}$. Urea could not, however, be detected after $5 \mathrm{~min}$ of incubation with the urease solution (data not shown).

\section{DISCUSSION}

\section{Urea turnover times and rate kinetics}

The turnover time of the urea pool varied between 36 and $133 \mathrm{~min}$ in the sediment surface $(0$ to $1 \mathrm{~cm}$ ) during the year and between $38 \mathrm{~min}$ and $17 \mathrm{~h}$ in deeper sediment strata. These rapid turnover times demonstrated that the urea pool in the sediment was very dynamic.

Urea turnover rates followed first-order rate kinetics throughout the year, as there was a linear relationship between the turnover rates and the concentrations of urea, and there was no relationship between $k_{\text {urea }}$ and the urea pool. The observed first-order rate kinetics for urea turnover was in agreement with previous pub-

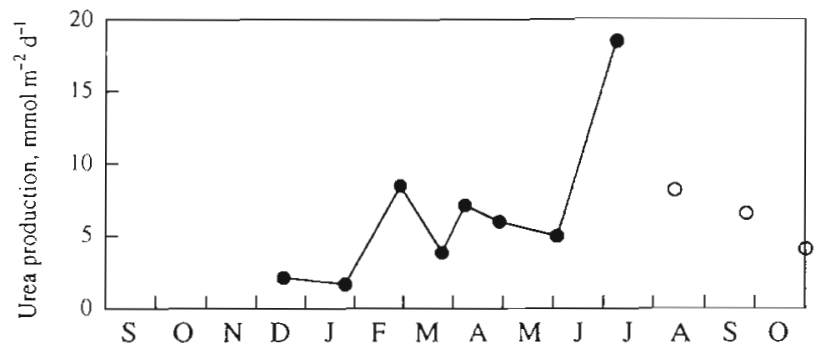

Fig. 5. Seasonal variation in integrated $(0$ to $16 \mathrm{~cm})$ urea production rates. 10 : calculated urea production rates, where urea efflux rates have not been included)

lished results from other marine sediments (Lomstein et al. 1989, Lund \& Blackburn 1989, Lomstein \& Blackburn 1992).

Bacterial urea turnover rates in natural environments are dependent on the concentration of urea, urea transport rates, the cellular levels of urease, and the $\mathrm{NH}_{4}{ }^{+}$transport rates (Mobley \& Hausinger 1989). The observed urea turnover rates were thus a result of several interdependent processes and factors. As the urea concentrations obtained in the present study were extremely low compared to known Michaelis constant, $K_{\mathrm{m}}$, values for urease, 0.1 to $100 \mathrm{mM}$ (e.g. Mobley \& Hausinger 1989), first-order rate kinetics were expected.

Laboratory experiments clearly demonstrated that all urea in the porewater was accessible for ureasecatalyzed turnover. As recognized by several authors that have studied amino acid turnover in sediments (e.g. Rosenfeld 1979, Christensen \& Blackburn 1980), it is important that the measured porewater concentration equals the metabolizable pool in order to calculate the actual turnover rate. The $100 \%$ turnover of urea in the porewater after 5 min of urease-incubation further showed that the component(s) in the porewater, which reacted with the reagents in the diacetylmonoxime method, could be turned over by urease. As urease specifically catalyzes the turnover of urea (Price \& Harrison 1987), it must have been urea which reacted with the reagents in the diacetylmonoxime method. Similarly, Lund \& Blackburn (1989) demonstrated that urea was not adsorbed or in other ways bound to the sediment, as they could recover $100 \%$ of the added ${ }^{14} \mathrm{C}$ urea as ${ }^{14} \mathrm{CO}_{2}$ after the time span of incubation. This could, however, have been due to the addition of a strong base $(\mathrm{NaOH})$ to the sediment.

\section{Urea turnover and temperature}

The urea turnover rate temperature coefficient, $Q_{10}=$ 2.3 , was within the range of 2 to 4 normally encoun- 
tered for biological rates (Klump \& Martens 1983). Similarly, $k_{\text {urea }}$ was dependent on temperature in the different sediment strata (Fig. 2b). As $k_{\text {urea }}$ is a combined measure for the activity and the amount of enzyme that hydrolyses urea, it is not possible from these data to conclude whether temperature stimulated urease activity and/or urease production.

\section{Urea production and urea pool size}

Urea production was stimulated by availability of high quality organic material, as proven by the positive relationship between the urea production rates and the $\mathrm{C} / \mathrm{N}$ ratios of the organic material in the sediment surface ( $r=0.75$; data not shown). Further, the temperature may also have stimulated urea production, as there was a positive relationship between integrated $(0$ to $16 \mathrm{~cm})$ urea production rates and temperature $(\mathrm{r}=$ 0.87 ; data not shown). It might be, however, that the temperature dependency was simply due to the fact that more high quality organic material was available during the times of the year when the temperature was also high. The highest urea production rate was found in July concurrent with maxima in C-mineralization, temperature, the quality of organic material (low $\mathrm{C} / \mathrm{N}$ ), and a high macrofaunal biomass. Urea is known to be produced by marine invertebrates (Wright 1975, Regnault 1987, Boucher \& Boucher-Rodoni 1988, Stickle 1988, Lomstein et al. 1989), but macrofaunal urea excretion only plays a minor role in the overall production of urea in the sediment (Lomstein et al. 1989). The stimulative effect of benthic macrofauna on sediment urea production may more likely have been due to the supply of degradable organic material to microorganisms associated with the burrow walls.

Urea comprised a significant proportion of the dissolved combined nitrogen compounds in the surface layer of this marine sediment. Urea- $\mathrm{N}$ made up between 7 and $55 \%$ of the total $\mathrm{NH}_{4}{ }^{+}+\mathrm{NO}_{3}{ }^{-}+\mathrm{NO}_{2}{ }^{-}+$ urea- $\mathrm{N}$ pool in the sediment 0 to $1 \mathrm{~cm}$ surface with maximum values in late February-April, August and November (data for $\mathrm{NH}_{4}{ }^{+}, \mathrm{NO}_{3}{ }^{-}$and $\mathrm{NO}_{2}{ }^{-}$not shown). Integrated $(0$ to $6 \mathrm{~cm}$ ) values revealed a similar seasonal pattern in the relative importance of urea, but in this sediment fraction urea-N only accounted for 3 to $24 \%$ of the dissolved combined nitrogen pool. There is, however, no discrepancy in the decrease in the relative importance of urea with sediment depth, as $\mathrm{NH}_{4}{ }^{+}$concentrations generally increase with depth and urea concentrations decrease. Urea concentrations are normally highest in sediment layers with high contents of high quality organic material. The secondary maxima in February-April and October-November thus coincided with major phytoplankton sedimentation events, which were detected in the sediment surface by increased chlorophyll $a+$ pheopigment contents and $a$ decrease in the $\mathrm{C} / \mathrm{N}$ ratio (Therkildsen \& Lomstein 1993). At present it is not quite clear why urea builds up in high concentrations in the sediment surface. It has, however, been suggested that the $\mathrm{O}_{2}$ concentration may be important in regulating the urea production/turnover regimes (Lomstein \& Blackburn 1992).

\section{Urea turnover and $\mathrm{NH}_{4}{ }^{+}$production}

The urea turnover could account for $80 \%$ of the calculated maximum net $\mathrm{NH}_{4}{ }^{+}$production $\left(2.9 \mathrm{~mol} \mathrm{~N} \mathrm{~m}{ }^{-2}\right.$ $\mathrm{yr}^{-1}$ ). A maximum estimate of the annual net $\mathrm{NH}_{4}{ }^{+}$ production could be calculated from the annual net C-mineralization rate (Therkildsen \& Lomstein 1993) and an assumed annual average $\mathrm{C} / \mathrm{N}$ ratio of 6.6 in the organic material that was mineralized. The $\mathrm{C} / \mathrm{N}$ ratio in the organic material that reached the sediment was likely to have been close to the Redfield ratio $(\mathrm{C} / \mathrm{N}=$ 6.6) due to the shallow water. Urea turnover has been shown to account for $100 \%$ of the net $\mathrm{NH}_{4}^{+}$production in defaunated sediment from the present location (Pedersen et al. 1993a). Based on a conceptual model of nitrogen mineralization, Lomstein et al. (1989) suggested that urea hydrolysis was responsible for up to $80 \%$ of the gross production of $\mathrm{NH}_{4}{ }^{+}$in Bering Shelf sediment and, similarly, urea turnover accounted for a major part of the $\mathrm{NH}_{4}{ }^{+}$production in Aarhus Bay sediment (Lomstein \& Blackburn 1992). The importance of urea turnover in the production of $\mathrm{NH}_{4}{ }^{+}$was further emphasized by the positive relationship between the integrated $\mathrm{NH}_{4}{ }^{+}$pools and urea turnover rates ( $\mathrm{r}=$ 0.66 ; data not shown).

Despite the intensive research on urea cycling in marine sediments during the past $5 \mathrm{yr}$, there are still numerous unanswered questions on the regulation of production and turnover of urea, and it is still unknown how the microorganisms benefit from urea turnover.

Acknowledgements. We thank $H$. Pedersen for valuable discussions. Financial support was obtained from the Danish Environmental Protection Agency, Marine Research Programme 90 , Grant no. 3-18.

\section{LITERATURE CITED}

Aarhus Amtskommune (1982). Undersøgelse af forureningstilstanden i Odder $\AA$ - Norsminde fjord 1975-1981. Aarhus Antskommune, Aarhus

Antia, N. J., Harrison, P. J., Oliveira, L. (1991). The role of dissolved organic nitrogen in phytoplankton nutrition, cell biology and ecology. Phycologia 30: 1-89

Boucher, G., Boucher-Rodoni, R. (1988). In situ measurement of respiratory metabolism and nitrogen fluxes at the interface of oyster beds. Mar. Ecol. Prog. Ser. 44: 229-238 
Christensen, D., Blackburn, T H. (1980). Turnover of tracer $\left({ }^{14} \mathrm{C},{ }^{3} \mathrm{H}\right.$ labelled) alanine in inshore marine sediments. Mar. Biol. 58: 97-103

Cochlan, W. P., Harrison, P. J. (1991). Uptake of nitrate, ammonium, and urea by nitrogen-starved cultures of Micromonas pusilla (Prasinophyceae): transient responses. J. Phycol. 27: 673-679

Eppley, R. W., Renger, E. H., Venrick, E. L., Mullin, M. M. (1973). A study of plankton dynamics and nutrient cycling in the central gyre of the north Pacific Ocean. Limnol. Oceanogr. 18: $534-551$

Gunkel, K., Jessen, H.-J. (1986). Untersuchungen über den Harnstoffeintrag in das Badewasser. Acta. hydrochim. hydrobiol. 14: 451-461

Gunkel, K., Kümmel, R., Tümpling, W. (1990). Zum biochemischen Harnstoffabbau in wässriger Lösung - Übersicht. Acta hydrochim. hydrobiol. 18: 3-20

Harrison, W. G., Head, E. J. H., Conover, R. J., Longhurst, A. R., Sameoto, D. D. (1985). The distribution and metabolism of urea in the eastern Canadian Arctic. Deep Sea Res. 32: $23-42$

Herbland, A. (1976). In situ utilization of urea in the euphotic zone of the tropical Atlantic. J. exp. mar. Biol. Ecol. 21: $269-277$

Klump, J. V., Martens, C. S. (1983). Benthic nitrogen regeneration. In: Carpenter, E. J., Capone, D. G. (eds.) Nitrogen in the marine environment. Academic Press, Inc., New York, p. $411-457$

Kokkinakis, S. A., Wheeler, P. A. (1988). Uptake of ammonium and urea in the northeast Pacific: comparison between netplankton and nanoplankton. Mar. Ecol. Prog. Ser. 43: 113-124

Lomstein, B. Ad., Blackburn, T. H., Henriksen, K. (1989). Aspects of nitrogen and carbon cycling in the northern Bering Shelf sediment. I. The significance of urea turnover in the mineralization of $\mathrm{NH}_{4}{ }^{+}$Mar. Ecol. Prog. Ser 57: 237-247

Lomstein, B. Aa., Blackburn, T. H. (1992). Sediment nitrogen cycling in Aarhus Bay, Denmark. Danish Environmental Protection Agency, Copenhagen

Lund, B. Aa., Blackburn, T. H. (1989). Urea turnover in a coastal marine sediment sediment measured by a ${ }^{14} \mathrm{C}$-urea short term incubation. J. microbiol. Meth. 9. $297-308$

McCarthy, J. J. (1970). A urease method for urea in seawater. Limnol. Oceanogr. 15: 309-313

McCarthy, J. J., Taylor, W. R., Taft, J. L. (1977). Nitrogenous nutrition of the plankton in the Chesapeake Bay. 1. Nutrient availability and phytoplankton preferences. Limnol Oceanogr. 22: 996-1011

This article was submitted to the editor
Mobley, H. L. T., Hausinger, R. P. (1989). Microbial ureases: significance, regulation, and molecular characterization. Microbiol. Rev. 53: 85-108

Paasche, E., Kristiansen, S. (1982). Nitrogen nutrition of phytoplankton in the Oslofjord. Estuar. coast. Shelf Sci. 14: $237-249$

Pedersen, H., Lomstein, B. Aa., Blackburn, T. H. (1993a) Evidence for bacterial urea production in marine sediments. FEMS Microbiol. Ecol. 12: 51-59

Pedersen, H., Lomstein, B. Aa., Isaksen, M., Blackburn, T. H. (1993b). Urea production by Thiosphaera pantotropha and by anaerobic enrichment cultures from marine sediments. FEMS Microbiol. Ecol. 13: 31-36

Price, N. M., Harrison, P. J. (1987). Comparison of methods for the analysis of dissolved urea in seawater. Mar. Biol. 94: $307-317$

Price, N. M., Harrison, P. J. (1988). Uptake of urea C and urea $N$ by the coastal marine diatom Thalassiosira pseudonana. Limnol. Oceanogr. 33: 528-537

Regnault, M. (1987). Nitrogen excretion in marine and freshwater crustacea. Microbiol. Rev. 62: 1-24

Remsen, C. C. (1971). The distribution of urea in coastal and oceanic waters. Limnol. Oceanogr. 16: 732-740

Remsen, C. C., Carpenter, E. J., Schroeder, B. W. (1974). The role of urea in marine microbial ecology. In: Colwell, $R$. R., Morita, R. Y. (eds.) Effects of the ocean environment on microbial activities. University Park Press, Baltimore, p. $86-304$

Rosenfeld, J. K. (1979). Amino acid diagenesis and adsorption in nearshore anoxic sediments. Limnol. Oceanogr. 24: $1014-1021$

Satoh, Y (1980). Production of urea by bacterial decomposition of organic matter including phytoplankton. Int. Rev. ges. Hydrobiol. 65: 295-301

Sörensson, F., Sahlsten, E. (1987). Nitrogen dynamics of a cyanobacteria bloom in the Baltic Sea: new versus regenerated production. Mar. Ecol. Prog. Ser. 37: 277-284

Stickle, W. B. (1988). Patterns of nitrogen excretion in the phylum Echinodermata. Comp. Biochem. Physiol. 91: 317-321

Therkildsen, M. S., Lomstein, B. Aa. (1993). Seasonal variation in net benthic $\mathrm{C}$-mineralization in a shallow estuary. FEMS Microbiol. Ecol. 12: 131-142

Vogels, G. D., Van der Drift, C. (1976). Degradation of purines and pyrimidines by microorganisms. Bacteriol. Rev. 40: 403-468

Wright, D. J. (1975). Elimination of nitrogenous compounds by Panagrellus redivivus, Goodey, 1945 (Nematoda: Cephalobidae). Comp. Biochem. Physiol. 52: 247-253

Manuscript first received: September 29, 1993

Revised version accepted: March 10, 1994 